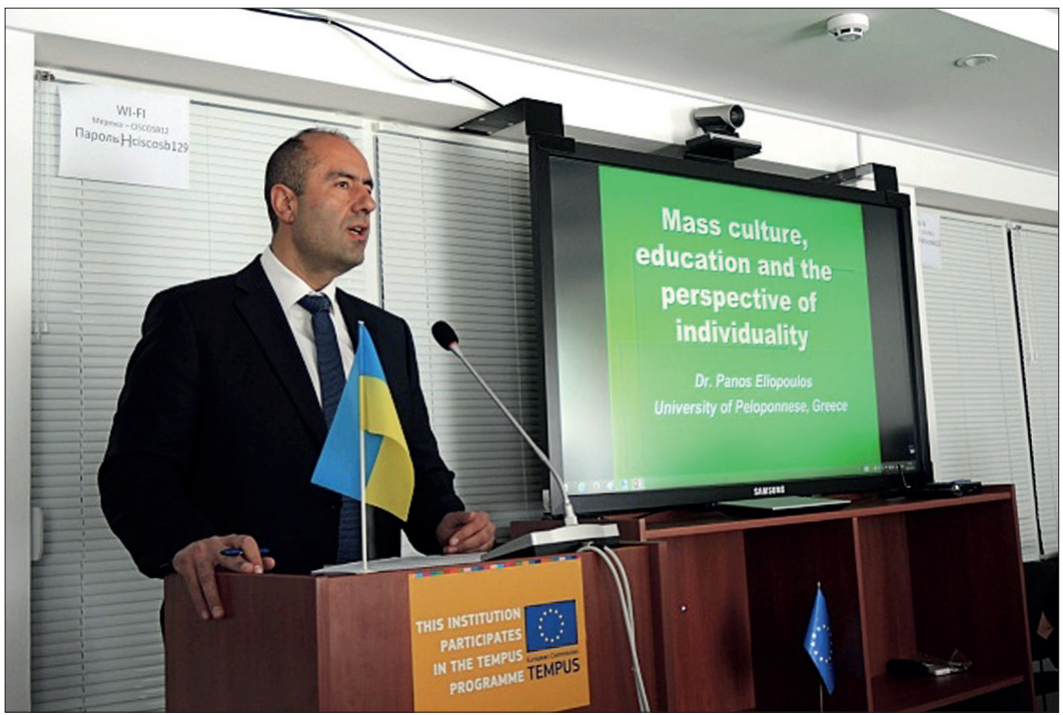

УДК: $130.2+37.03$

\title{
MASS CULTURE, EDUCATION AND THE PERSPECTIVE OF INDIVIDUALITY
}

\section{Methodological seminar was conducted by the scientific journal "Philosophy of Education" (Institute of Higher Education, National Academy of Educational Sciences of Ukraine)}

The participants of the seminar were Prof. Panos Eliopoulos (University of Peloponnese, Greece), Lyudmyla Gorbunova, Mykhailo Boychenko, Olga Gomilko, Mariia Kultaieva, Volodymyr Kovtunets, Sergiy Kurbatov, Anna Laktionova, Tetiana Matusevych,

Natalia Radionova, Iryna Stepanenko, Maya Trynyak and Viktor Zinchenko.

On March 30, 2016 a methodological seminar was conducted at Institute of Higher Education NAES of Ukraine. This seminar was devoted to the discussion of educational problems in the area of mass culture, and relative opportunities for the development of individuality. The report "Mass culture, education and the perspective of individuality» was made by Panos Eliopulos, professor of Peloponnese University, a member of journal's «Філософія освіти. Philosophy of Education" editorial board. The scientists from Institute of Higher Education, Institute of Philosophy of the National Academy of Sciences of Ukraine, Taras Shevchenko National University of Kyiv, Skovoroda National Pedagogical University of Kharkiv participated in this event.

Designated issues were observed primarily from the point of view of the Frankfurt School representatives, as well as representatives of modern critical philosophy of 
education and critical pedagogy. It was emphasized that T.Adorno's ideas and ideas of other Frankfurt School members, which were developed in the middle of the last century, continue to be relevant in current socio-cultural contexts. The technical rationalism which became the the rationalism of dominance in the context of technological civilization, could not provide the way toward the liberation of man and the development of his or her individuality. Market society with its instrumental rationality leads to homogenisation and standardization of mass culture and as a result we have a semi-education, leading to destruction of personality and social pathologies. The panelists agreed that semi-education reflects the crisis of ideals of education and training as far as a suspension of human emancipation process. Due to suspension of the creative process of a person formation, replacing it by the processes of stereotyping based on mimetic rationality, culture itself loses creative potential. The process of degradation of education and culture in the semi-education eventually leads to its destruction at theoretical level and the elaboration of the practice of anti-education.

Only through returning of the individual and maintaining his or her social importance due to the tools of holistic education it is possible to overcome such stereotyping. For Frankfurt School members, and those who share their ideals, true education in its meta-theoretical sense becomes the important factor, contributing to the emancipation of society and individual. This idea is particularly important in the context of contemporary challenges and threats from instrumentalization of approaches to the process of transformation of the Ukrainian culture and education.

Keywords: Adorno, Horkheimer, Frankfurt School, mass culture, education, semieducation, anti-education, personality.

\section{Lyudmyla Gorbunova}

Our workshop is devoted to the important problem, which is indicated as a title of the presentation by Professor Panos Eliopoulos «Mass culture, education and the perspective of individuality».

Dear Professor! Thank you for the interesting presentation and for your participation in our seminar.

Dear colleagues! Let's start the discussion about indicated problems. You are welcome to ask your questions. I use my right of moderator and put my questions first.

How do you define «mass culture», «popular culture», «folk culture», «elite culture»? What are the differences between «high» and «low» culture? Where are the boundary between them? What are the criteria of their differentiation? Do you consider «mass culture» as a space of dialogue between the different subcultures or diffusion space between the high and low, complex and simple?

\section{Panos Eliopoulos}

To some extent, some of these terms appear today as interchangeable, able to form certain groups between them. In this case, each term owes its separate 
existence mostly to a difference in tone, rather than denote a profound semantic difference. For example, popular culture is the one which meets a wide consensus by the public, actually the mainstream in entertainment, fashion, etc. Popular culture stresses the feature of being chosen by the people, usually disregarding other criteria than enjoyment or what could be called elements belonging to "a public aesthetics". Folk culture, on the other hand, places the emphasis mostly on place, perhaps even on ethnic characteristics which do not refer exclusively to common origins and group identity but also to common outlets of expression, artistic or other. Also in folk culture we suppose the characteristic of tradition; something that is not expected, in the same depth, in popular culture. Elite culture refers to that culture whose main component is its axiological reference to a group that is either esteemed by others as a separate group or it esteems itself as such. Elite culture is supposed to be based on a sharp differentiation between other cultures that it considers as belonging to larger or less significant groups. An elite culture cannot belong to the many, so its value originates also from numerical associations within societies. Now, high culture typically means the number of cultural products which are given axiological priority, especially in the arts. A sonata by Liszt belongs to a "shopping bag" of high culture as opposed to a song by the rock band Nirvana. So high culture also contains an aristocratic element and it avoidably negotiates its departure from the wide public mass. Low culture is primarily a derogatory term, for certain forms in popular culture which "experts" do not think high of.

Seeing that as part of a cultural system or a system of cultures, this is supposed to be a subsystem, although its massive acceptance gifts it with an enormous interest for study due to its proliferation. As regards mass culture I would note that it can be seen in a positive and in a negative sense. The negative sense stems from the expansion of cultural products of low value to all social classes. In the negative sense, mass culture is "distributed" to citizens rather than being created by them or for them. It often reflects "artificial" needs that have been invented in continuation to their working time. Mass culture is now popular culture and one time in the future it may well acquire the features of locality and tradition; thus it may be transformed to folk culture. In the positive sense, mass culture could potentially represent the ecumenical access of all citizens to cultural products which they will pursue, as seekers of wisdom or enjoyment, not as mere and obedient consumers. Mass culture, in that sense, could be the border of resistance to the omnipresent danger of the disenchantment of our world. In the particular context mass culture would be able to incorporate dialogical or dialectical elements which would be passing to the masses not in a mechanical and blindly self- reproducing manner, but in a way that is critically self- defining and self- evaluating. The problem in the connection of the above is that academic definition neglects to focus on the practical resolution, partly 
due to an incomplete awareness of the interconnections and interchangeability of the above. For instance, mass culture mechanics connote an influence of popularity that, in our century, may at times acquire even the disguise of the elite (despite the obstacle of the numerical reference) or even of a certain "theology of the product", leaving out all the "non- believers" (the non- barbarians as Ortega y Gasset would have called them).

Nowadays, with the reversal of this typical pyramid, the "elite" may as well refer to large numbers of people who become hostile to non -elites, those who do not get inspired by the mass cultural products. This overturning of terms, while it becomes inevitably interesting for analysis, from another aspect it makes difficult to predict the ability of evolution of these cultural systems. Thus the problem has two main heads: one is the unpredictability of the forms of certain cultural systems, and another is the absence of suggestions that would act in assistance of practical resolution. Education remains trapped in the form of half- education, serving specific norms and ignoring the liberating force of other forms that could be born in free cultural and social discourse.

\section{Mykhailo Boychenko}

What role could a community play in the development of human individuality? We know, that different communities produce different types of personalities and therefore different possibilities for the development of individuality of each person. Modern community, for example, our philosophical community, supports critical thinking and encourages individualization, while traditional community, for example, religious fundamentalist community, develops loyalty and teamwork, but hardly promotes true identity.

\section{Panos Eliopoulos}

It is necessary to evoke Wittgenstein, so as to explore the meanings of the employed terms: "community", "identity", "individual", "different", "critical", etc. Wittgenstein would remind us that it is one thing to be certain about something and another thing to know something. The latter would mean to be able to prove it beyond any possible doubt. To pose one related question, in answer to yours, how would we "know" what individuality truly means before rushing to serve it as a given aim? How would we define "critical thinking", even in a solely functional Habermasian level of social and academic consensus? Before this goes too far, I would say that, from a personal point of view, I would not oppose to Aristotle's understanding of the community as a form of life that is there in order to enhance the individual possibilities for Eudaimonia. What this further implies is that, first, it is important to set the goal and then to decide the means; so what is the goal of modern societies? Is it other than financial growth and stability? Is financial growth and stability not taken 
in our communities as the building block of our western democracies? In this possible confinement of political theory within the bars set by financial theory, the community may have to re- invent its targets. The community has to think of the individual not only as its building block but of individuality as the central capacity that it contains. Unfortunately, capitalism seems to share a common view of the human being, along with Marxism: that man is a simple being, namely a homo economicus. To serve this dimension of the human being is to enslave man to production, to one-sided entertainment, to a schopenhauerean pendulum between boredom and anticipation. In that sense, maybe, in the past, what we would call now "traditional communities" could have promoted individual self- identity as a product of loyalty to a common cause, a cause chosen freely by the individuals, as in the case of the hoplites of ancient Athens. Thus, I would not see the term "traditional community" only in the light of restrictive religiosity or disappearance of the individual.

\section{Sergiy Kurbatov}

Thank you, Professor Eliopoulos, for an interesting presentation! You tried to analyze really important problems and has a solid theoretical background, based on the works of representatives of Frankfurt school and other prominent philosophers of the last century. But during last few decades the situation not only in the area of humanities, but in the development of civilization as such changed dramatically. Alvin Toffler, who is still alive 1, in 1970 identified the situation of a contemporary man as a "future shock" and it was few decades before mass spreading of Internet and communicative and digital revolutions! I understand that there are certain "eternal truth" in the area of philosophy and we need to protect the right on such philosophical truth in our area of knowledge, but I am wondering how these fundamental changes in the life of our civilization influenced current interpretation of the approaches, provided by Theodor Adorno and other philosophers, which you mentioned in your presentation. So, my question is: was the problem of surviving of individuality in the time of mass culture and the role of education in this process researched in English language literature during last decade? And, if yes, could you provide a brief review of the relevant literature?

\section{Panos Eliopoulos}

Very interestingly there has been a number of books that deal with this problematic area. Among the secondary bibliography I would particularly draw focus on books related with the work of Adorno who most explicitly encounters this issue. I would shed particular light to the substantive works of Sherman

${ }^{1}$ Unfortunately, on June, 27, 2016 a famous American social thinker Alvin Toffler (1928-2016) passed away. 
2007, Cook 2008, Schweppenhдuser 2009, Honneth 2009, Zuidervaart 2011, O'Connor 2013, Bowie 2013, the wonderful book of McArthur 2013, Freyenhagen 2013. Even more than these books and others, I would like to stress the importance of Landy and Saler 2009 (The Re-Enchantment of the World: Secular Magic in a Rational Age), where they argue that the enchanting possibilities latent in ordinary speech were also brought to the fore by Ludwig Wittgenstein. Wittgenstein seemed eager to turn to mass culture as a resource for innovative perspectives, because he felt free to advance unconventional hypotheses. Wittgenstein noted that mass culture could generate forms of enchantment that were compatible with the secular rationality of his age.

\section{Volodymyr Kovtunets}

My question concerns mission of education from different religious points of view. At the World Congress on Catholic Education last year speakers often emphasized position: "We don't sell education services, we have specific mission in education". Could you comment the difference between the positions of Orthodox and Catholic churches concerning mission of education in modern world?

\section{Panos Eliopoulos}

Christian churches, on the whole, in our times, find it very important to address the needs of the modern person in terms of soteriology, as in the past. However, there is also now evident a transfer to the field of values, where certain references fulfill the criterion sought in mundane living. Both churches, I am sure, do a tremendous work in preserving and proliferating a great number of values which remain significant, perhaps more than ever, for our social coexistence. Nonetheless, there are historical factors behind this effort that aid in the decisive formation of the whole context. The Catholic Church has shown a different attitude to the quest for ecumenicality in the past, one that bears strong political characteristics, especially in certain periods. The Orthodox Church, on the contrary, has been proved to be less attached to the political.

In this spirit, there seems to be a subsequent respective multidimensional resort to methods and approaches in education. While I am not an expert in religious matters, I would add that the religious point of view is a necessary point of view in education, especially when it manages to discard the political element. One thing indeed is not to sell education services; another of course would be not to imbue education with political attributes. I strongly believe and I hope that both churches would refrain from such a practice. In the philosophy of education it has often been attested that religious missions of education could be the "fast track" to the attainment of values. While it is socially questionable whether one can imbue the young generations with certain ethical 
elements of thought and behavior, for the believer it is much more feasible to obtain access to the practice of these elements. William James, the American pragmatist said in one of his lectures in the beginning of the 20th century that the most important thing one can know about a man is his personal beliefs, his convictions. I side with his remark: religious convictions, in an atmosphere of acceptance and tolerance for whatever or whoever is heterodox, should not create a hostile environment for values which our society desperately needs. In that sense, education springing from religious traditions, even other than the Christian, would be extremely welcome and, I think, quite efficient.

\section{Tetiana Matusevych}

Discussing the problem of the dominant mass culture, it is necessary to address the subject of conscious and unconscious retranslation of stereotypes (particularly gender) in the educational process. Can we get rid of it, and whether should we do this?

\section{Panos Eliopoulos}

In my opinion, gender, despite the barriers it could set, at the same time it is a liberating force, a basis for one's personal and professional development, a unique mark of individuality. Avoiding a crisis of the logical and ethical conceptions, one could put forward his/her inner talents and determination for work and success. As the Spanish existentialist Ortega y Gaset suggests one need to focus on his/her vital sensitiveness, exactly the aspect that rationalist practice misses. Being able to remain in the place of subjective awareness will generate the ability for objective utility that will allow one to be functional, effective and free from misconception. However it remains true that it is only ethical that all participants in any part of the social arena be given equal and unimpeded opportunity and this should never consist a basis for negotiation.

\section{Tetiana Matusevych}

Focusing on the implementation of gender-equality policies in education in transitive societies such as Ukrainian, I find that the "problem" is the key word in this process. It is important to mention that the importance of the transformational role of gender mainstreaming in education for societies in transition lies in the fact that gender approach is problem-posing by its nature; it involves analysis of socio-cultural reality and its subsequent problematization and deconstruction. The distribution of gender relations throughout all aspects of everyday life allows teachers and students to analyze the usual phenomena of disparity and to look for creative ways to deconstruct them.

Also the usage of adequate methodological tools in the educational process is a very important issue. Methodological frameworks that enable us to 
consider gender mainstreaming in education as a factor in building a democratic society are interdisciplinarity, transversality and the rejection of any "centrisms", transgression, and transculturality. The introduction of gender courses into the curriculum requires a teacher's readiness to employ innovative ways of developing deep self-reflection and creative thinking as well as innovative ways of reformatting the student-teacher interaction to reflect the new gender perspective. One of these innovative pedagogies is a dialogic communication method that is free of gender stereotypes. It is both an interpersonal and professional communication that entails a "co-evolutionary" process whereby students' and teachers' personal development causes transformational shifts in student-teacher relations. The aim of these new relations is to democratize the educational processes, to establish a culture of freedom, which is a prerequisite for autopoiesis (i.e., self-creation) and development "transgressive" personalities. The tandem of freedom and self-reflection (as both a value and the methodological framework of gender-oriented education) provides an indispensable basis for the development of creativity.

\section{Lyudmyla Gorbunova}

I think that "mass culture" is not a culture in the strict sense of this word, but a form of cultural development under the conditions of industrial and postindustrial development as far as mass industrial society. Specific peculiarities of "mass culture" are accessibility, seriality, machine reproducibility and its own character code, a kind of symbolic superstructure above the structures of real everyday life, which plays a role of a complete equivalent of reality as such. These features are necessary and sufficient for clarification of ideal and typical attributes of mass culture. All other features - commercial character, hedonism, poor intellectual content, simplification of aesthetic forms, etc - are either secondary, or optional. During the analyses of the concrete cases they could be observed only sometimes.

To my mind, the most interesting definition of mass culture was elaborated by Daniel Bell and representatives of Birmingham school of cultural studies the mass culture is a kind of organization of ordinary consciousness (and also sense creation) in informational society; the specific sign system or particular language through which the members of informational society could understand each other. This system is a kind of link between the postindustrial society with the high level of specialization and a human being, who is integrated in it as a "partial man" ("one-dimensional man" by Herbert Marcuse). The communication between these "partial men", narrow specialists, is possible, unfortunately, only at the level of "mass man" - in other words, through mediation of a certain average popular language, which is represented by mass culture. 
Spreading of the processes of globalization, informational and communicative revolutions, increasing the level of urbanization, migration processes and social mobility - these are the main conditions of the life of contemporary man. A man feels fluidity, flexibility of the world, dynamic character of environment. The cultural boundaries become mobile and transparent. A man is becoming a transcultural nomade, and as a result, "the citizen of the world".

As we know, human individuality is created in cultural environment, which is surrounded a man since the movement of his or her birth. At the same time, the culture is realized due to purposeful and meaningful activity of a man and such activity has individual character. Individual is becoming a person due to his or her freedom and involvement in the world of culture that is when he or she becomes a medium of the senses of social life and the source of its development. The society need to support the development of person and his or her individuality, because here we have deal with the creative potential of this particular society and its culture.

But the cultural creativity needs internal and external freedom, which is the highest value for the society and the person. Unfortunately, not everyone is relevant to this high criterium (due to abilities and specific nurturing). "To be free", in this case, means a huge work, eternal struggle and creative search together with the absence of quietness. Only the creative persons could choose this way of life, because alternative ways are impossible for them. In order to satisfy their needs the majority of people use the routine schemes and stereotypes. As a result they become an object of manipulation by the system and civilization. Their "vital world", as Jurgen Habermas mentioned, is colonized by system of market relations and power.

What is the role of education in providing opposition to such colonization, in saving and returning of individual as a subject and creator of culture?

First of all we need to provide individual with the strong cultural (multicultural) background, in the framework of which he or she could create own individual transversal and transcultural bridges. We think that only transversality provides us with the possibility of positive scenario of future global culture. Such polyembeddedness in numerous culture, but not monoembeddedness in particular ethnical culture or subculture could give possibility to achieve the freedom of creativity in cosmopolitan civil perspective "between" and "above" the cultures.

This leads to the formation of transversal and transcultural competence, heterologous type of thinking, which is characterized individual as a virtually universal subject. Such education assumes the development of communicative rationality, which includes orientation toward post-conventional values, human rights and high moral responsibility. 
Creation of critical thinking, which assumes transgression beyond imposed paradigms, schemes and stereotypes as a mechanism of resistance to manipulative (goal oriented rational, strategic and instrumental) influence on person, provides us with the possibility of the freedom of the choice. This is the main message of Henry Giroux, Peter McLaren, Paulo Freire, Ivan Illich, Jack Mezirow and other representatives of critical pedagogy and the theory of adult education. This message is reflected in the papers and analytical reviews of literature in our journal ${ }^{1}$.

This type of education is possible only in the framework of humanitarian content and humanistic orientation of education, especially philosophical education, which is constantly stressed in UNESCO documents.

Unfortunately, the reformation of Ukrainian education according to quasi neoliberal understanding is occurring as its transformation in profitable sector of market economy, which is competitive only in short-term perspective. In the middle-term and especially in historical perspective such approach leads to transformation of education in a kind of mass culture, which provides people with a kind of semi knowledge instead of real knowledge. The recipients of such semi knowledge become "mass customers" as a part of manipulated "mass" or "black hole of sociality" as Jose Ortega-y-Gasset and representatives of Frankfurt school mentioned.

\section{Mykhailo Boychenko}

In postmodern society we meet different communities and therefore different strategies for individualization. We can not say which one would be more successful in the near future - moreover in the far future. After Theodor Adorno, Max Horkheimer, Jose Ortega y Gasset and Herbert Marcuse - Zigmunt Bauman also tells us about liquid modernity as well liquid social identity in the society of social masses - it can be true, but this kind of identity could not constitutes any stable community. So we risk to loose the understanding of a community at all - but not the community in their reality. Mass society swallows communities, but can not to dissolve them and so it risks to choke by them. So we can not to underestimate the role of communities: any evaluation is possible only from the point of view of the representative of some community - no one is a person "per se", in itself, unless in his/her own imagination. But according to Cornelius Castoriadis the world of the imaginary is also the social, common and mutual world - or at least becomes. We should take social values not as something already given for us and identical for everybody, but as

${ }^{1}$ Макларен П. Революційна критична педагогіка у XXI ст. / Філософія освіти, № 1-2 (9), 2010. - С.31-66; Горбунова Л. Теорія трансформативного навчання: освіта для дорослих в умовах «плинної сучасності» / Філософія освіти. Philosophy of Education. № 2 (13), 2013. - C.66-114. 
something that we need an effort to think out, to get along together - on the basis of common experience. So we should first be a part of common life-world and then a constructers or re-constructers of a social institutions. Mass society is not an exception. It consists of a several life-worlds of different communities, so it needs in symbolic system general to all these communities. This symbolic system is some kind of hyper-reality, so every person could create his/her own path from the values of community to this system - it is a question of taste or motivation, not of violence or manipulation. There could be some behavioral rules typical for certain community or social norms typical for certain social system but there can not be unchanged laws or incontestable standards. So education should be also oriented on values of communities - real communities of society: local communities, professional communities, educational communities. The opposition of person as individuality and mass society is false - always community matters first.

\section{Viktor Zinchenko}

Dear Professor Eliopoulos drew attention to the role of research of critical theory to the problems of mass culture, education and individuality. In this regard, I want to focus on modern (the end of XX, beginning of XXI century) trends and concepts in this direction. Especially my focus would be on «Critical social philosophy of education».

In modern concepts of critical social philosophy of education and critical (or Radical) Pedagogy (Douglas Kellner, Richard Lichtman, Henry A. Giroux, Peter McLaren, Mark A. Foster, George Kneller, Rainer Winter, Michael Vavrus, Glenn Rikowski etc.) in the context of institutional trends in public life, it is believed that globalization and the technological revolution must be used for a radical restructuring and reconstruction of education to serve democracy and progressive social change.

Throughout his philosophical adventures, D. Kellner has drawn from the Frankfurt School a concern for the industrialization and commercialization of culture under capitalist relations of production. This situation has become most acute in the United States with its highly commercial media culture. Combining insights and methodological tools from the Frankfurt School and from British cultural studies, Kellner has written on media culture as a complex political, philosophical, and economic phenomenon. Douglas Kellner is an academic who works at the intersection of «third generation» critical theory in the tradition of the Frankfurt Institute for Social Research, or Frankfurt School and in cultural studies in the tradition of the Birmingham Centre for Contemporary Cultural Studies, also known as the «Birmingham School». He has argued that these two conflicting philosophies are in fact compatible. He is currently the George Kneller Chair in the Philosophy of Education in the 
Graduate School of Education and Information Studies at the University of California, Los Angeles.

In his view, media emerges as a "contested terrain" in which political struggles are played out in narrative and visual forms. Thus films, television, internet, etc. articulate dominant, conservative, reactionary social values but also offer progressive resistance against these values.

A major theme in many of H.Giroux's texts is the media's representations of youth. He argues that youth serve as a scapegoat for many social problems and that they are commodified by our corporate culture. Like Paulo Freire, Giroux believes that educators need to understand their students and to address the contexts of their everyday lives. As such, he argues for a pedagogy that critically examines the media and other cultural artifacts that shape students cultural contexts but that are nevertheless frequently ignored in classrooms. The media enacts its own invisible pedagogy, constructing representations of race, class, gender, ethnicity, sexuality, occupation, age, etc. on the screen. A critical media pedagogy seeks to make visible how and why these representations are constructed, to ask whose interests they serve, and to locate sites of resistance to disabling representations and oppressive cultural narratives.

D.Kellner was an early theorist of the field of critical media literacy and has been a leading theorist of media culture generally. In his recent work, he has increasingly argued that media culture has become dominated by the forms of spectacle and mega-spectacle. He also has contributed important studies of alter-globalization processes, and has always been concerned with counterhegemonic movements and alternative cultural expressions in the name of a more radically democratic society. More recently, he is known for his work exploring the politically oppositional potentials of new media and attempted to delineate what they term "multiple technoliteracies" as a movement away from the present attempt to standardize a corporatist form of computer literacy.

Two books appeared which constitute one of the first systematic attempts to show the critiques of education by Herbert Marcuse and his pedagogical alternatives in "Marcuse's Challenge to Education", co-edited with K. Daniel Cho, Tyson E. Lewis, and Clayton Pierce (Rowman and Littlefield Publishers, 2009). This is a reader that has many essays pertinent to Marcuse's critique and reconstruction of education.

"Marcuse's Challenge to Education" seeks to demonstrate the continued relevance and importance of Marcuse's thought to the contemporary situation and present a series of articles that, each in their own way, speak to the ongoing challenge offered by Marcuse for critical theory and transformative practice in the present era. Our focus in this book is on Marcuse's critical analysis of education in the current era of global capitalism and his potential for generating transformative pedagogical practice and the reconstruction of schooling 
and society. With the rise of standardization policies in the sphere of schooling, the steady growth of the "affluent society" within Western, post-industrialized economies, the waning of dialectical thinking in the field of philosophy and theory, the immediate degradation of the environment, a dispiriting era of war and militarism, and the rise of a militant anti-corporate globalization movement, Marcuse speaks with clarity to academics, teachers, and activists interested in understanding the complexities of "counter-revolution and revolt" occurring today in a variety of locations and across a variety of domains. In book "On Marcuse: Critique, Liberation, and Reschooling in the Radical Pedagogy of Herbert Marcuse" attempts to show that Herbert Marcuse continues to have significant relevance and importance to the contemporary situation concerning education in the advanced, industrial world. With the rise of standardization policies in the sphere of schooling, the steady progress of the "affluent society" in the sphere of western, industrialized economies, the waning of critical and dialectical thinking in the field of philosophy and the social sciences, and finally, the immediate degradation of the environment, Marcuse speaks with clarity to academics, teachers, and activists interested in understanding the complexities of "counter-revolution and revolt" occurring today in a variety of locations and across many domains.

Other major work constitutes a reader "Media/Cultural Studies: Critical Approaches", co-edited with Rhonda Hammer appearing with Peter Lang Publishing. This text contains an overview by Douglas Kellner and Rhonda Hammer of media and cultural studies and a new paradigm that combines media/communication studies with cultural studies. Contributions engage contemporary media, consumer, and digital culture.

Media Culture develops methods and analyses of contemporary film, television, music and other artifacts to discern their nature and effects and argues that media culture is the dominant form of culture which socializes us and provides materials for identity and both social reproduction and change. (D.Kellner "Media Culture: Cultural Studies, Identity and Politics Between the Modern and the Postmodern").

\section{Anna Laktionova}

When we concern education process that aims to support a personality of human being in terms of individuality (resistant to the possibility and inclination of being dissolved in and by mass culture, not reducible to producer and customer roles) we can involve the issues connected with rationality. Individual and common rationality are philosophical concepts that are in need of clarification and constructing their reciprocal links.

If we speak of individuals, it presupposes implicitly or explicitly individual rationality. Rationality could now be seen (in this particular context) as rea- 
sonability, as a general basis for support individual mechanisms of expressing oneself, reacting to other individuals etc., thus providing diverse forms of cooperation about different contents. If we strive to grow via education an individual (that relies on individual rationality) to prevent his/her dissolving in mass culture and his/her loosing of him/herself (distorting or, even, neglecting of his/her value as such) we should take into consideration the way that common (reciprocal) actions would take.

The last presupposes common (collective rationality) which cannot be reduced just to the sum of individual rationalities. If it could such common rationality would be completely bounded only by reciprocal exchange, use, make profit of one another. Such picture is not acceptable and does not differ much from what is unsatisfactory in mass culture.

In such a way we face a paradox: if we grow individuals we cannot avoid masses. Maybe cultural mass is not just evil; it is unavoidable and even positive in some sense. The problem is that we want to 'save' individuality, upper value of person. In doing that it seems important to teach and share experience of common (collective) rationality and consequently acting. Such rationality and actions could become a true positive way or tool for individual to improve his/ her personality instead of loosing it in mass. So, the concept of 'mass' itself needs reconsideration.

\section{Natalia Radionova}

I propose to the colleagues a kind of imaginary dialogue between Ukrainian philosopher Grigory Skovoroda (1722-1794) and the Representatives of the Frankfurt School. My considerations on the matter of our discussion have an aim to reflect some processes on the boundaries of the problem field of this seminar, but nevertheless are very important for intercultural communication in Ukrainian contexts. I think also that they may be regarded as a contribution to the problem of the relationship between education, culture and individuality in historical dimension as a communication between the early and later Modernity. The same attempt is already done in the monograph of Axel Honneth "The Pathologies of Individual Freedom. Hegel's Social Theory" (2010), where Hegel is speaking with the Frankfurters und through them to us. To make a comparison between the philosophical views of Grigory Skovoroda and Th. Adorno's conception of the half-education is very actual, because it deals with the problem of cultural alienation. Their dialogue is possible as a discourse in the problem field of the popular philosophy as an effective educational practice realized by Grigory Skovoroda. As the philosopher of freedom he has developed a conception of individual approach to education connected with the Christian ethic. That is very similar to Hegel's concept of the ethical life and makes impossible any half-education. Of course, the imaginary dia- 
logue between these great philosophers has many problem lines, that may be the matter of the next discussions.

\section{Iryna Stepanenko}

Panos Eliopoloulos highlighted the problems concerning the relationship between education and society. This issue is no less relevant today than half a century ago, when the representatives of Frankfurt school developed it.

Stereotypical reactions and mental clichйs, which are produced by the industry of mass culture and mass media, continue to threaten our rationality and our rational perception of the world. It occurs even more than before due to the emergence of new powerful means of manipulation of human consciousness.

Our life is still damaged by capitalist-driven society with its focus on maximum profit and benefits in all spheres of social life. As Adorno maintains in his book Minima Moralia, - "What philosophy once called life, has turned into the sphere of the private and then merely of consumption, which is dragged along as an addendum of the material production-process, without autonomy

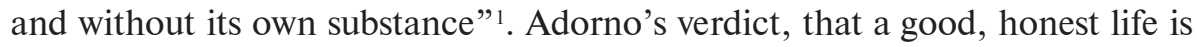
no longer possible as we live in an inhuman society, retains its validity today. But if in the mid-twentieth century higher education, because of its elitism, in many respects still retained its own internal preconditions for intellectual development, at the end of the twentieth century the situation did not change for the better.

The laws of the market are penetrating into the sphere of higher education and begin modeling it as a mass industry of production knowledge as consumer goods. Standardization and massification entered the field of higher education and led to the threat of its McDonaldization ${ }^{2}$. But here we can detect a paradox.

On the one hand, the need for higher education to go beyond the narrow confines of economic feasibility within the broader scope of the sustainable development is underlined in all international documents. All those who defend the humanistic approach in education recognize that "Education alone cannot hope to solve all development challenges, but a humanistic and holistic approach to education can and should contribute to achieving a new development model. In such a model, economic growth must be guided by environmental stewardship and by concern for peace, inclusion and social justice. The

\footnotetext{
${ }^{1}$ Adorno T. Minima Moralia http://users.clas.ufl.edu/burt/MinimaMoralia_Full.pdf

${ }^{2}$ Altbach Philip G. Franchising - The McDonaldization of Higher Education / Philip G. Altbach // International Higher Education. - 2012/ - № 66. - 7-8. Scott P. Massification, internationalization, and globalization. - [Electronic resource]. - Mode of access: WWW.URL: // The globalization of higher education. Ed. by Scott Buckingham, UK: SRHE \& Open University Press, 1998. Pp. 108-129.
} 
ethical and moral principles of a humanistic approach to development stand against violence, intolerance, discrimination and exclusion. Regarding education and learning, it means going beyond narrow utilitarianism and economism to integrate the multiple dimensions of human existence"

On the other hand, since the higher education has become a competitive enterprise and rushes for income and prestige its fundamental role as a public good is being easily neglected 2 .

In the early 21 st century, higher education has become a competitive enterprise and HEI is gradually becoming, in the best case, the enterprise for the production of knowledge-goods, in the worst case - in a kind of supermarket, where knowledge - goods you can buy and sell. It destroys the inner good of educational practice and "can also contribute to a decline in a sense of academic community, mission and traditional values" 3 .

This paradox is inspired by the victory of instrumental and consumer rationality. The representatives of the Frankfurt school warned about this danger. But the irony of this victory is that consumer rationality not only destroyed the roots of the liberation of human and society, but more over it constitutes a threat to the destruction of humanity in general.

Therefore Universities have to find the way to integrate their competition for status, ranking, funding from governmental or private sources with their internal mission as a public good. It is stressed in The 2030 Agenda for Sustainable Development, - "In a globalized world with unresolved social, political, economic and environmental challenges, education that helps build peaceful and sustainable societies is essential ${ }^{4}$.

This understanding should be formed by all participants of the educational process and at all levels, especially at the level of governance and public management. One more point to be understood is that "The content of such education must be relevant, with a focus on both cognitive and non-cognitive aspects of learning. The knowledge, skills, values and attitudes required by citizens to lead productive lives, make informed decisions and assume active roles locally

\footnotetext{
${ }^{1}$ Rethinking Education: Towards a global common good? Published in 2015 by UNESCO p.10 http://www.unesco.org/new/fileadmin/MULTIMEDIA/FIELD/Cairo/ images/RethinkingEducation.pdf

${ }^{2}$ Trends in Global Higher Education: Tracking an Academic Revolution. A Report Prepared for the UNESCO 2009 World Conference on Higher Education Philip G. Altbach, Liz Reisberg, Laura E. Rumbley. Published in 2009 by the United Nations Educational, Scientific and Cultural Organization. http://unesdoc.unesco.org/ images/0018/001831/183168e.pdf.

${ }^{3}$ ibid., p. ii

4 United Nations. 2015. Transforming our world: the 2030 Agenda for Sustainable Development. P. 49 https://sustainabledevelopment.un.org/post2015/ transformingourworld.)
} 
and globally in facing and resolving global challenges can be acquired through education for sustainable development (ESD) and global citizenship education (GCED), which includes peace and human rights education as well as intercultural education and education for international understanding. While considerable progress has been made in recent years, only 50\% of UNESCO's Member States indicate that they have, for example, integrated ESD into relevant policies ${ }^{1}$.

Education, in light of the 2030 Agenda for Sustainable Development, in order to overcome the Half - Education, "shall aim at the full development of the human personality and promote mutual understanding, tolerance, friendship and peace". ${ }^{2}$.

Relevant and realistic intermediate benchmarks and stepping stones should be set at the national level to achieve this goal. "This must include changes as appropriate in education content, approaches, structures and funding strategies to address the situation of excluded children, youth and adults" ${ }^{3}$. Special attention should be paid to learning outcomes: "Relevant learning outcomes must be well defined in cognitive and non-cognitive domains, and continually assessed as an integral part of the teaching and learning process. Quality education includes the development of those skills, values, attitudes and knowledge that enable citizens to lead healthy and fulfilled lives, make informed decisions and respond to local and global challenges. A focus on quality and innovation will also require strengthening science, technology, engineering and mathematics education (STEM)" ${ }^{4}$. Higher education, if it really wants to overcome the state of Half - Education, should focus on the challenges of the future to form not just "atomized" intellectual, who is busy with "game in beads", but to produce a responsible intellectual, who is able to work in a team and is aware of his concern for his own self-development and life creation, for the fate of other people, native society and the world in general.

And collapse threatens humanity not only because global problems have not been solved, but because of the rise of the Fourth Industrial Revolution. As experts of the World Economic Forum predict, robots will take about 2/3 jobs and will be able to fully learn the function of technical rationality in the near future. Five years from now, over one-third of skills (35\%) that are considered important in today's workforce will have changed. The 10 skills you need to thrive in the Fourth Industrial Revolution are the following: 1. Complex problem solving; 2. Critical thinking. 3. Creativity; 4. People management;

\footnotetext{
${ }^{1}$ United Nations. 2015. Transforming our world: the 2030 Agenda for Sustainable Development. P. 49 https://sustainabledevelopment.un.org/post2015/transformingourworld

${ }^{2}$ ibid.,p. 28

${ }^{3}$ ibid.,p. 32

${ }^{4}$ ibid.,p. 33
} 
5. Coordination with other; 6 . Emotional intelligence; 7. Judgment and decision making; 8 . Service orientation; 9. Negotiation; 10. Cognitive flexibility 1. The list of these 10 skills significantly enrich the portrait of the modern intellectual. They also should be considered when finding ways to overcome the half-education and developing of the new intellectual prerequisites and aims at education.

\section{Maya Trynyak}

The issues which were raised by respected professor Panos Eliopoulos in his presentation are extremely typical for Ukrainian present especially in the part of new cultural medium and educational space forming where individuality must feel comfortable and harmonically.

Such outstanding thinkers as Theodor Adorno, Max Horkheimer, Ortega y Gasset and Herbert Marcuse ideas analysis acquires a special value for native scientists which are to construct strategies of successful Ukrainian future attainment including such spheres as education, science and culture by ways of theirs reformation and modernization. It is clear that in this report professor could not touch all sides of the announced issues and proposed characteristics of all possible risks which appears under the conditions of globalization and integration proses which Ukraine is going through nowadays but, to my opinion, it would be expedient to raise the issue of individuality safety as a value under such the conditions. Besides, Ukrainians are to answer multiculturalism' calls worthily demonstrating high level of intercultural preparation but under the condition of national identification safety at the same time.

Philosophical realization of multiculturalism issues today is not only a try to answer theoretical questions as for society, culture and education development but a try to construct practical recommendations as for reduction and softness of pressure on human being which feels lost in the situation of cultural diversity.

It should be noted that multiculturalism as a phenomenon and as an ideology permanently is placed in sight of modern philosophical thought. Consideration of existentially - anthropological basis of this phenomenon has principal meaning for logic of social study and education understanding in the situation of cultures collision, and also for results of education globalization and integration processes evaluation first of all in high education, what demonstrates tendency not only or wideness but for deepness as well during last years.

It is clear that within the framework of one report it is impossible to analyze all issues connected with the announced topic so proposed be me the above can be considered as a wish as for perspective lined of future cooperation.

\footnotetext{
${ }^{1}$ The 10 skills you need to thrive in the Fourth Industrial Revolution. https://www weforum.org/agenda/2016/01/the-10-skills-you-need-to-thrive-in-the-fourth-industrialrevolution
} 


\section{Olga Gomilko}

I want to start with one story. Not long ago during my classes at university I would often refer to Hollywood blockbusters, e.g. the movies by Christopher Nolan, when reflecting on some philosophical topics. My students used to respond abruptly "We do not watch a Hollywood trash". I also recall my male fellow students inviting us, girls to a football game, upon which we would say that "Football is not an aesthetic sight to behold". Recently I've come across a paper on philosophy of music that was dedicated to the analysis of the negative influence of electronic dance music (EDM) on personal development of young people! All of these examples demonstrate a consistent negative reaction to mass culture. Since it is deprived of a creative cultural potential, which is why education appears its antidote. Theodor Adorno's, Max Horkheimer's, Ortega y Gasset's and Herbert Marcuse's ideas discussed in Panos Eliopoulos' speech provide support for such an approach. Technical rationalism becomes a conceptual accusation of tragic events in the past century. On the one hand, two totalitarian regimes managed to come into being thanks to a strong propaganda, on the other hand, Soviet totalitarianism saw a moral threat in bourgeois mass culture. Hence, mass culture was facing blows from all sides.

However, the current situation seems to change its stance on mass culture. J. Ranciure speaks of an aesthetical revolution, thanks to which the hierarchy (established by the representative regime of art) of the aesthetical is being destroyed. The aesthetical revolution's achievement is overcoming of established boundaries between the visible and invisible, the heard and misheard, the conceivable and inconceivable, knowledge and action, activity and passivity, etc. Consequently, forms of culture acquire their aesthetical status, which they have previously been shorn off. Moreover, J. Ranciure speaks of the tendency to a stronger politicization of the aesthetical. Unlike the classical propaganda that functions along with the representative regime of art and acknowledges the hierarchy of the aesthetical, the contemporary mass culture arises from its overcoming and expresses an insuperable contradiction between the representative and aesthetical art regimes. Therefore, Hollywood blockbusters or the EDM fulfill their own aesthetical function that makes the politicization of the aesthetical as a way of its connection with life's practice possible. Instead of manipulating the consciousness, as the classical propaganda did, the contemporary mass culture should encourage distillation of consciousness, i.e. its filtration from archaic layers of aggression and violence.

The de-hierarchization of the aesthetical also changes significantly one's attitude towards sport, which was also deleted from the aesthetical experience in the sphere of mass culture. Hans Gumbrecht speaks of praise of athletic beauty in terms of "democratization of the aesthetical experience". The hierarchical distinction between traditional forms of "high culture" and phe- 
nomena of "mass culture" is also overcome by the aestheticization of sport. It implies the revelation of such aesthetical functions of sports that render human sensibility more balanced and rationally manageable. The acknowledgment of the aesthetical attractiveness of sport makes it an efficient tool for the influence of human sensations. "Concentrated tension" in sport compels physical and emotional abilities to perform at their very best. It is no coincidence that sport has found its honorary place at American universities, whereas other forms of mass culture require their acknowledgment in the world not as alternatives to "high culture", but as its aesthetical partners.

\section{Mariia Kultaieva}

In the context of today presentation it would be interesting to analyze the understanding of education in the legacy of the Frankfurt School. The experience gained by the Frankfurt School in the problem field of coherence between mass culture, education and development of the individuality is successful with the great heuristic potential. The ideas of Th. Adorno and other representatives of the Frankfurt School, developed in the middle of the last century, remain actually in contemporary social-cultural contexts. In this connection I should like pay attention to two moments. The first deals with precision of the concept Bildung (education) developed by the German idealism, because the founder generation of the Frankfurt School has used this term in Hegelian tradition and the concept of "half-education" is its negative, the semantic of which as an instrumental approach to education is else more radicalized in the concept Unbildung (non-education), proposed of the young generation of the Frankfurters for the diagnostics of pathologies in culture and human being. The second moment applies to phenomenon of individuality and its self-representation in the contemporary world reflected in philosophical explorations A. Honneth's, P. Sloterdijk, K. P. Liessmann's.

It must be mentioned that the German word "Bildung" usually is translated as "education", but through Kant, Fichte and especially Hegel this concept has significant extended its content, partly coinciding with the concepts of culture and ethical life, which takes an important part in Hegel's social theory. One of the consequences of these semantic changes is the difficulty of its translation that is impossible without reducing of complexity. All this provokes to cross uncontrolled from the macro-level theory to the micro-level reflection of practice and reversed. Anyway, this displacing becomes a methodological status in Adorno's works which are devoted to the capitalist form of life in its cultural dimension and educational implications. It must be reminded, that his diagnostics of half-education was suggested not only by disgraceful practice "immediately connecting" of German universities to the ideological machinery of the Third Reich or by influence of the mass culture as aculture industry. 
Not least the theory of half- education was founded on Adorno's impressions and teaching skills gained from his first exile station in England where the philosopher was needed to do the impossible things: to reduce irreducibilities that means adaptation of very refined meta-theoretical German terminology to Anglo-Saxon styling of philosophical thinking. This remark was done by $\mathrm{R}$. Dahrendorf his attempt to clear the intellectual discomfort of this significant representative of the Frankfurt school in the frames foreign cultural and educational tradition (Dahrendorf Ralf. Versuchungender Unfreiheit. Die Intellektuellen in Zeiten der Profung.- Mьnchen: C.BeckVerlag. 2006, S. 158-159). Anyway the matter the university's destiny explicated in Adorno's normativecultural paradigm, has become a new articulation today. Especially the facts making evident this tendency are summarized in the fundamental research made by M. Roche (Roche Mark. Was die deutschen Universitzten von den amerikanischen lernen kцnnen und was sie vermeiden sollen. Hamburg: MeinerVerlag. 2014).

The perspective of every nation depends on its education, but another question must be also placed into the front line in the age of the globalization and in the contexts of postindustrial transformations: how much half-education with its specified cultural and social learning each nation on its local space without to be replaced in the postcolonial relations or postmodern slavery? The American universities have enough resources to make that without any restriction and danger to destroy both: the educational system and social life. The elite universities in the USA have immunity against the pathologies of the halfeducation what the most European Universities do not possess. Even this Universities and not the celebrated European institutions of the high education can be named the custodian of University Idea in the constellations of the later Modernity. The losers become in the games of globalization the only possibility of the half-education in the form of receiving modernization. Once more it may be emphasized that the half-education is the way to lost the majority that means the last stage in the dialectic of Enlightenment. That is why the whole education (Bildung) in its meta-theoretical sense must be maintained as an emancipatory factor in the transformations of society and human being. It is also the necessary normative ideal of society.

It must be also made the difference in the interpretative possibilities used for description of social pathologies operating with the concept of half-education and those, that can be used for the whole and opened education. As an ideal-typical construction it contributes to disillusion of social consciousness what is important for opening perspectives for individual and cooperative selfactualization. All that means the return to the options of the whole and opened education (Bildung) in the process of forming responsible subject of the social life. Not coincidentally Hegel and after him the Frankfurter tried to find differ- 
ent ways to connect the concept of education with the conception of the ethical life as the contra-facticity to reality of culture industry.

To clear the second moment mentioned above, which has some connotation with ethical life and its life-world, we must once more return to hidden senses in the concept of "Bildung" in all its important connotations, used or misused in the discourses of social and educational philosophy. In German philosophical tradition this concept has preserved senses derivate from its inside form - Bild (picture, sight, figure, shape, formation). At the metatheoretical level education (Bildung) means a cultural and intellectual shaping of personality. The human is both the creation and the creator of culture. This dialectic unveils in the education process including the practices of selfeducation connected with self-knowing. For example, P. Sloterdijk had made an attempt to visualize this process with sport terminology. Sending message to all people that they must change itself and their life he understands education as a training process with the anthropological premise that human being needs exercises to shape not only the body, but also the spirituality and ethical life. His conception of the post-passivity of the man making exercises provides the activation of mechanism of the self-observation and self-control by creating the individuality of a new kind - on the other side of passive subjects formed in practices of the half-education. The real education is always both - atopic and local present, isolate and connected with humanities. The principles of non-conclusion, non-satisfaction of the human subject with the results of his self-actualization create the atmosphere of freedom inquiry on non- pragmatically learning. The aim of the real education is freedom. The goals of its educational practices converge in human emancipation, which really has right for claim: no limits to human learning. This kind of education can't be interrupted by getting diplomas and scientific degrees. Just the opposite is the half-education that always reproduce only itself and makes human clones. In its mimetic rationality has lost the ability to create ideals, values and form personality. This pathology can be showed symptomatically as an autopoietically damage (in terminology of N. Luhmann) or inability to produce innovative sights (Bilderlosigkeit in terms of Th. Adorno). That can be caused by social or by human condition. Both are often accompanied by denying of philosophy as the ground of critical thinking and rational proofed propositions how to treat the pathologies of reason and individual freedom which is necessary for democracy and democratic way of life.

This tendency is also remarkable in the Ukrainian social and cultural reality, where philosophy is regarded in the logic of the half-education, is incompatible with the European idea. The degradation process of culture, education and individuality manifested in the half-education can be continued in the theory and practice of non-education, that are even more aggressive as those 
of the half-education in the context of delusion. K.P. Liessmann in his explorations devoted to this obstructive pathology shows the phenomena of the noneducation taking place in the Bologna process appreciated by him as a killer of European universities, in the myth of the knowledge-society, in uncritically applications of the competence approach and media-pedagogics, especially power point presentations. Non-education is associated here with the empty forms of educational practices and dysfunctional educational innovation presented as reforms or new pedagogical technologies as legitimated practices of a new barbarism.

The break through this eclipse of reason (M. Horkheimer) at the pathologies of individual freedom can be realized in struggles for recognitions (A. Honneth) or "through the revolution in the second person singularity" (P. Sloterdijk), which should propose the intentional changes of self-educating human.

Масова культура, освіта і перспектива індивідуальності. Методологічний семінар в редакції журналу «Філософія освіти. Philosophy of Education» (Інститут вищої освіти НАПН України)

Участники семінару: проф. Панос Еліопулос (проф.,Університет Пелопоннеса, Греція), Людмила Горбунова (д.філос.н., голов. редактор журналу, ІВО), Михайло Бойченко (д.філос.н., проф. каф. філософії КНУ), Ольга Гомілко (д.філос.н., провід.н.співроб. Інституту філософії НАНУ), Віктор Зінченко (д.філос.н., проф., голов.н.співроб., ІВО), Марія Култаєва (д.філос.н., проф., зав.каф. філософії ХНПУ), Сергій Курбатов (д.філос.н., зав.відділом, IBO), Володимир Ковтунець (к.фіз.-мат.н., заступ. директора, IBO), Анна Лактіонова (докторант каф. філософії КНУ), Тетяна Матусевич (к.філос.н., директор Центру міжнарод.співпраці і європ.інтеграції НПУ), Ірина Степаненко (д.філос.н., проф., зав відділом, IBO), Майя Триняк (д.філос.н., проф. каф. філософії ХНПУ), Наталія Радіонова (д.філос.н., проф. каф. філософії ХНПУ).

30 березня в Інституті вищої освіти НАПН України відбувся методологічний семінар, присвячений обговоренню освітніх проблем та можливостей для розвитку індивідуальності, що виникають у просторі масової культури. 3 доповіддю «Масова культура, освіта і перспектива індивідуальності» виступив професор Університету Пелопоннеса, член редакційної колегії журналу «Філософія освіти. Philosophy of Education» Панос Еліопулос. В дискусії взяли участь науковці з Інституту вищої освіти НАПН України, Інституту філософії НАН України, Київського національного університету імені Тараса Шевченка, Харківського національного педагогічного університету імені Г.С.Сковороди.

Поставлені проблеми розглядалися переважно з точки зору представників Франкфуртської школи, а також представників сучасної критичної філософії освіти і критичної педагогіки. Було підкреслено, що ідеї Т.Адорно та 
інших представників Франкфуртської школи, які розроблялися у середині минулого століття, не втратили актуальності й у сучасних соціокультурних контекстах. В умовах технологічної цивілізації технічний раціоналізм, який стає раціоналізмом панування, не в змозі забезпечити шлях до звільнення людини і розвитку іiі індивідуальності. Ринкове суспільство з його інструментальною раціональністю веде до гомогенізації і стандартизації масової культури, проявом якої є напівосвіта, яка призводить до руйнації особистості та соціальних патологій. Учасники дискусії зійшлися на думці, що напівосвіта - це криза ідеалів освіти й виховання, призупинення процесу емансипації людини. Внаслідок заміни творчого процесу формування людини процесами стереотипізації на основі міметичної раціональності втрачає свій креативний потенціал і сама культура. Процес деградації освіти і культури у напівосвіті зрештою призводить до іiі знищення у теорії і практиці анти-освіти.

Прорив крізь таку стереотипізацію може бути здійсненим через повернення індивіда та усвідомлення суспільної значущості індивіда, насамперед, завдяки засобам цілісної освіти. Для представників Франкфуртської школи і тих, хто поділяє їх ідеали, справжня освіта у іiі метатеоретичному сенсі набуває значення чинника, що сприяє емансипації суспільства та людини. Ця думка стає особливо важливою в контексті сучасних викликів і загроз інструменталізації в підходах до процесів трансформації української культури і освіти.

Ключові слова: Адорно, Горкгаймер, Франкфуртська школа, масова культура, освіта, напівосвіта, анти-освіта, індивідуальність.

Массовая культура, образование и перспектива индивидуальности. Методологический семинар в редакции журнала «Філософія освіти. Philosophy of Education» (Институт высшего образования НАПН Украины)

30 марта в Институте высшего образования НАПН Украины состоялся методологический семинар, который был посвящен обсуждению образовательных проблем, возникающих в пространстве массовой культуры, и в связи с этим возможностей для развития индивидуальности. С докладом «Массовая культура, образование и перспектива индивидуальности» выступил профессор Университета Пелопоннеса, член редакционной коллегии журнала «Філософія освіти. Philosophy of Education» Панос Елиопулос. В дискуссии приняли участие ученые из Института высшего образования НАПН Украины, Института философии НАН Украины, Киевского национального университета имени Тараса Шевченко, Харьковского национального педагогического университета имени Г.С.Сковороды.

Поставленные проблемы рассматривались преимущественно с точки зрения представителей Франкфуртской школы, а также представителей современной критической философии образования и критической педагогики. Было подчеркнуто, что идеи Т.Адорно и других представителей Франк- 
фуртской школы, которые разрабатывались в середине прошлого столетия, не утратили своей актуальности и в современных социокультурных контекстах. В условиях технологической цивилизации технический рационализм, который становится рационализмом господства, не в состоянии обеспечить путь к освобождению человека и развитию его индивидуальности. Рыночное общество с его инструментальной рациональностью ведет к гомогенизации и стандартизации массовой культуры, результатом которой является полу-образование, ведущее к разрушению личности и социальным патологиям. Участники дискуссии сошлись во мнении, что полу-образование - это кризис идеалов образования и воспитания, приостановка процесса эмансипации человека. Вследствие замены творческого процесса формирования человека процессами стеретипизации на основе миметической рациональности теряет свой креативный потенциал и сама культура. Процесс деградации образования и культуры в полу-образовании в конечном итоге приводит к ее уничтожению в теории и практике анти-образования.

Прорыв сквозь такую стереотипизацию может быть осуществлен через возвращение индивида и осознание общественной значимости индивида, прежде всего, благодаря средствам подлинного образования. Для представителей Франкфуртской школы и тех, кто разделяет их идеалы, настоящее образование в его метатеоретическом смысле приобретает значение фактора, способствующего эмансипации общества и человека. Эта мысль становится особенно важной в контексте современных вызовов и угроз инструментализации в подходах к процессам трансформации украинской культуры и образования.

Ключевые слова: Адорно, Хоркхаймер, Франкфуртская школа, массовая культура, образование, полу-образование, анти-образование, индивидуальность.

Підготовлено до друку Людмилою Горбуновою і Сергієм Курбатовим 